\title{
Egg Quality of Hens Fed Different Digestible Lysine and Arginine Levels
}

http://dx.doi.org/10.1590/1516-635x170163-68

\section{-Author(s)}

Carvalho FB de

Stringhini $J \mathrm{H}$

Matos MS'

Café $M B^{\prime}$

Leandro NSM

Gomes NA'

Santana ES

Jardim Filho RM'

UFG, Escola de Veterinária e Zootecnia, Departamento de Produção Animal, Goiânia, GO.

\section{ABSTRACT}

This experiment aimed at evaluating the influence of the supplementation of digestible lysine and digestible arginine at different ratios in the diet fed to layers between 24 to 44 weeks of age on egg quality. In total,320 Lohmann LSL laying hens were allotted according to a completely randomized design in a $2 \times 4$ factorial arrangement, consisting of two digestible lysine levels (700 or $900 \mathrm{mg} / \mathrm{kg}$ of diet) and four digestible arginine levels (700,800,900,or $1000 \mathrm{mg} / \mathrm{kg}$ of diet). Diets contained, therefore, digestible Lys:Arg ratios of 100, 114, 128, and 142 when the diet contained $700 \mathrm{mg}$ digestible lysine per $\mathrm{kg}$ of diet, and 78, 89, 100, and 111 when 900 mg digestible lysine per kg was supplemented. The data obtained with digestible arginine levels were fitted to polynomial regression equations, and with digestible lysine, the $\mathrm{F}$ test ( $5 \%$ probability) was used to compare the means. The following variables were evaluated: egg weight; internal egg quality (yolk percentage and index, albumen percentage, Haugh units), eggshell quality (specific gravity andeggshell percentage); and whole egg, albumen, and yolk solids content. Digestible lysine and arginine interaction did not affect egg quality. Increasing levels of digestible lysine and arginine reduced eggshell quality and albumen solids, respectively. The levels of these amino acids suggested to improveegg quality are $700 \mathrm{mg}$ digestible lysine and $700 \mathrm{mg}$ digestible arginine/ $\mathrm{kg}$ of feed at a Dig Lys: Dig Arg ratio of 100.

\section{INTRODUCTION}

Carvalho FB de

Rua 132A, Qd45, lote 05, Setor Sul, CEP 74093-220, Goiânia, GO

E-mail: fabyolab@hotmail.com

\section{nKeywords}

Antagonism, digestible amino acid, egg components, Haugh units.
According to Campos et al. (2012), lysine is the second limiting amino acid, after the sulfur amino acids in poultry avian diets. However, high lysine intakemay negatively influence amino acid balance, reducing feed intake and increasing amino acid excretion. Therefore, the dietary balance between lysine and arginine is essential.

Arginine is synthetized from glutamate and ornithine, which is produced in the liver of mammals as part of the urea cycle (Lehninger et al., 1995). On the other hand, poultry are not able to synthetize ornithine from glutamate because they lack the enzymespyrroline-5carboxylatesynthase (converts glutamate to glutamate-5-phosphate) and ornithine-aminotransferase (transfers the amine grouping of glutamate for glutamate-5-phosphate to produce ornithine) and cannot convert ornithine in citrulline because of the absence of ornithinetranscarbamylase (responsible for converting carbamoyl phosphate and ornithine into citrulline) which prevents the occurrence of the urea cycle in birds. Therefore, poultry arginine requirements are much higher relative to mammals (Bacila, 2003). In addition, because poultry diets are based on corn and soybean meal, where arginine is considered limiting, this amino acid must be supplied (Edmonds et al., 1985). 
Moreover, there are clear evidences of considerable antagonism between arginine and lysine. When L-amino acids with similar chemical structure are unbalanced in the diet, the urinary excretion of amino acid at with the lowest concentration increases (Nunes, 1998). The excess of lysine may reduce the activity of the enzyme glycine-amidino transferase in the liver, and thereby may limit the production of creatine. Excessive lysine levels in poultry diets may lead to competition of lysine with arginine for kidney tubular reabsorption, because both amino acids have the same absorption site, which may lead to increasing kidney arginase activity, which oxidizes arginine in ornithine and urea. This demonstrates that high levels of dietary lysine increase arginine requirement (Macari et al., 2002). In experiments to determine lysine requirements, arginine should be the limiting amino acid in order to maintain the maximum expression of the genetic potential by chickens (Gadelha et al., 2003).

The National Research Council (NRC, 1994) recommendation for laying hens is $0.7 \%$ total arginine for a feed intake of $100 \mathrm{~g} / \mathrm{hen} /$ day and $0.88 \%$ for a feed intake of $80 \mathrm{~g} / \mathrm{bird} /$ day. Rostagno et al. (2011) suggested level of $0.866 \%$ of digestible arginine for a feed intake of $93 \mathrm{~g} / \mathrm{hen} /$ day, $0.804 \%$ for a feed intake of $100 \mathrm{~g} / \mathrm{hen} / \mathrm{day}$, and $0.748 \%$ for a feed intake of 108 $\mathrm{g} /$ hen/day layers. The Lohmann LSL manual for white layers (Lohmann LSL, 2004) makes recommendations according to production phase and not to feed intake, with $1.08 \%$ total arginine for $90 \%$ of lay, $0.99 \%$ total arginine for $89-80 \%$ of lay, and $0.95 \%$ total arginine for less than $80 \%$ of lay.

In this context, the optimal levels of arginine and lysine need to be determined in order to prevent the antagonism between these amino acids, which may negatively affect egg quality. Therefore, this study aimed at evaluating the influence of the dietary digestible lysine and digestible arginine supplementation at different ratios on the egg quality of laying hens between 24 and 44 weeks of age.

\section{MATERIAL AND METHODS}

The experiment was carried out in the facilities of the Federal University of Goiás, Goiânia, Brazil. A total number of 320 24-week-old Lohmann LSL layers were housed in 40 conventional cages $(40 \times 100 \times 42 \mathrm{~cm})$ in an experimental laying house with concrete floor, at eight hens per cage (two per pen). The cages were equipped with nipple drinkers and individual trough feeders. Hours of light were gradually increased until the on set of lay, and reached 17 hours at the peak of lay (34 weeks of age). An automatic timer to control the lighting program and 60-W lamps were used.

Diets were fed ad libitum twice a day, in the morning (8:00m) and afternoon (16:00m). Temperature and air humidity levels inside the experimental facilities were recorded daily at 8:00m and 17:00m using a thermo-hygrometer. Average minimum and maximum temperatures of 20.15 and $30.33^{\circ} \mathrm{C}$, and 69.1 and $87.2 \%$ average minimum and maximum relative humidity values were recorded.

A completely randomized design in a $2 \times 4$ factorial arrangement was applied, with eight treatments and four replicates of 10 hens each (five pens with two hens each). Two digestible lysine levels (700 or 900 $\mathrm{mg} / \mathrm{kg}$ of diet) were combined with four digestible arginine levels $(700,800,900$, or $1000 \mathrm{mg} / \mathrm{kg}$ of diet), resulting in digestible lysine to digestible arginine ratios of $100,114,128$ and 142 when the diet with $700 \mathrm{mg}$ lysine was fed, and 78, 89, 100, and 111 when 900 mg lysine was fed.

The formulation of the experimental diets was based on the ingredient composition and nutritional requirements proposed by Rostagno et al. (2000). The diets contained $2800 \mathrm{kcal}$ of metabolizable energy/ $\mathrm{kg}$ of diet and $16 \%$ crude protein (Table 1). Lysine$\mathrm{HCl}(0.178$ and $0.202 \%)$ was added to diets to obtain 700 and $900 \mathrm{mg}$ of digestible lysine per $\mathrm{kg}$ of diet, and $0.0,0.105,0.211$, and $0.316 \%$ of L-Arginine to supply the proposed levels of 700,800,900, and 1000 $\mathrm{mg}$ of digestible arginine. Amino acids were added in replacement of cassava starch.

Five periods of 28 days were evaluated (from 24 to 44 week of age). During the last three days of each 28-day experimental period, a sample of 16 eggs per treatment was collected. Intact eggs, yolks and eggshells were weighed in a digital scale (Chyo Petit Balance, model MK 500 C, Moretti, Argentina) with $0.01 \mathrm{~g}$ precision. Before weighing, the eggshell of each egg was washed and dried in a forced-ventilation oven at $55^{\circ} \mathrm{C}$ for 24 hours. Albumen weight was obtained by difference between egg weight and the weights of the eggshell and of the yolk. The weight of all egg components is expressed as percentages of total egg weight.

Yolk index was calculated as a quotient between yolk height, measured with a micrometer (Ames S-6428), and yolk diameter measured using a caliper. In order to determine Haugh units, eggs were broken on a plate and albumen height was measured using a micrometer (Ames S-6428). Haugh units were calculated according to the following logarithmic expression: $U H=100 \mathrm{log}$ 
Table 1 - Composition and calculated nutritional values of the basal diet.

\begin{tabular}{|c|c|}
\hline Ingredient & (g/kg, as fed) \\
\hline Corn & 646 \\
\hline Soybean meal $42 \%$ & 97 \\
\hline Wheat bran & 55 \\
\hline Corn gluten $60 \%$ & 55 \\
\hline Limestone & 90 \\
\hline Meat meal & 40 \\
\hline Salt & 0.039 \\
\hline Mineral and vitamin supplementation* & 0.012 \\
\hline L-Lysine HCL & 0.017 \\
\hline L-Arginine $\mathrm{HCl}$ & 0.000 \\
\hline DL-Methionine 99 & 0.016 \\
\hline L-Tryptophan & 0.007 \\
\hline Starch & 0.061 \\
\hline Total & 100 \\
\hline Metabolizable energy (kcal/kg) & 2,800 \\
\hline Crude protein $(\mathrm{g} / \mathrm{kg})$ & 160 \\
\hline Calcium $(\mathrm{g} / \mathrm{kg})$ & 40.5 \\
\hline Available phosphorous (g/kg) & 3.8 \\
\hline Lysine $(\mathrm{g} / \mathrm{kg})$ & 7.7 \\
\hline Digestibel lysine(g/kg) & 7.0 \\
\hline Arginine $(\mathrm{g} / \mathrm{kg})$ & 7.5 \\
\hline Digestible arginine $(\mathrm{g} / \mathrm{kg})$ & 7.0 \\
\hline Methionine + cystine $(\mathrm{g} / \mathrm{kg})$ & 6.9 \\
\hline Methionine $(\mathrm{g} / \mathrm{kg})$ & 3.9 \\
\hline Threonine (g/kg) & 5.9 \\
\hline Tryptophan(g/kg) & 2.0 \\
\hline Arginine:Lysine & 1.00 \\
\hline
\end{tabular}

* Mineral and vitamin supplement (composition/kg of feed): Vit. A-2,500,000 IU, Vit. D3-625,000 IU, Vit.-E 3750 mg, Vit. K3-500 mg, B1-500 mg, B2-1000 mg, B6-1000 mg, B12-3,750 mcg, Niacin-7,500 mg, Acid pantohenate-4,000 mg, Biotin-15 mg, Folic acid-125 mg, Choline-75,000 mg, Selenium- 45 mg, lodine-175 mg, Iron-12,525 mg, Copper-2,500 mg, Manganese-19,500 mg, Zinc-13,750 mg, Avilamicin-20,000 mg.

$(H-1.7 W+7.6)$, where $H$ is dense albumen height $(\mathrm{mm})$ and Wis egg weight (g).

Specific gravity was determined in eggs collected during the last two days of each 28-d period, by immersing eggs in buckets containing different saline solutions $(\mathrm{NaCl})$, which densities ranged from 1.065 to 1.100 at 0.005 intervals, as calibrated with densitometer (Incoterm 5599). The specific saline solution in which the egg floated was individually recorded for all treatments.

In order to calculate total egg, yolk, and albumen solids, 12 eggs per treatment were broken and placed in individual recipients. Egg components were separated, weighed, and dried in a forced-ventilation oven at $65 \pm 5^{\circ} \mathrm{Cfor} 72$ hours and, after this, in an oven at $105^{\circ} \mathrm{C}$ for 24 hours, then the residues weighed.
For statistical analysis, theaverage ofthe data obtained in the five periods was calculated (from 24 to 44 week of age). The averages were then submitted to analysis of variance using the statistical program SAEG (Versão 7.1) at 5\% probability level. The four levels of digestible arginine tested were submitted to polynomial regression analyses.

\section{RESULTS AND DISCUSSION}

No statistical interaction of dietary digestible lysine and digestible arginine supplementation were observed for average egg weight (Table 2). Therefore, the different digestible lysine: digestible arginine ratios evaluated in this experiment did not affect the weight of the eggs or of its components. However, Araújo et al. (2005), testing six digestible lysine: arginine ratios (718:716, 790:716, 718:644, 790:644, 718:788, and $790: 788 \mathrm{mg} / \mathrm{kg}$ of diet) in Lohmann Brown and Lohmann LSL 40-week-old layers, obtained lower egg weight when the diet contained the ratio of 790:716 digestible lysine: arginine/ $\mathrm{kg}$ of diet. Lima \& Silva (2007) fed white and brown layers with diets containing two digestible lysine levels (710 or $780 \mathrm{mg} / \mathrm{kg}$ of diet) and three digestible arginine levels $(640,720$, or $790 \mathrm{mg} / \mathrm{kg}$ of diet) and observed significant interaction effects. When layers were fed $720 \mathrm{mg}$ digestible arginine/kg of diet, heavier eggs were obtained with the lowest digestible lysine level $(710 \mathrm{mg} / \mathrm{kg}$ of diet). When the diet contained $780 \mathrm{mg}$ digestible lysine $/ \mathrm{kg}$ of diet, the heaviest eggs were obtained when 790 $\mathrm{mg}$ digestible arginine/kg of diet were fed. Those authors observed that digestible arginine levels must be adjusted as digestible lysine levels increase. This result was not observed in the present experiment because the increase in lysine and arginine dietary levels did not affect egg weight and the lowest digestible lysine and digestible arginine ratio (100) seemed to be sufficient to maintain egg quality.

Average egg weight, and albumen and yolk percentages were not influenced by the evaluated digestible lysine and arginine levelswhen individually analyzed (Table 2).

Increasing dietary digestible lysine levels have been previously studied (Silva et al., 2010; Jardim Filho et al., 2010) and the results indicated that higher lysine levels resulted in heavier eggs, higher albumen percentage (Jardim Filho et al., 2008; Schmidt et al., 2008; Silva et al., 2010; Jardim Filho et al., 2010), and higher yolk percentage (Schmidt et al., 2008; Rocha et al., 2009; Jardim Filho et al., 2010; Silva et al., 2010). Other authors found increased egg weight with 770 
Table 2 - Egg quality evaluation for laying hens fed different levels of digestible lysine (Lys, mg/kg of diet) and arginine (Arg, $\mathrm{mg} / \mathrm{kg}$ of diet) from 24 to 44 week of age.

\begin{tabular}{|c|c|c|c|c|}
\hline & Egg weight (g) & Eggshell (\%) & Albumen (\%) & Yolk (\%) \\
\hline \multicolumn{5}{|c|}{ Digestible lysine } \\
\hline 700 & 58.84 & $9.50 \mathrm{a}$ & 64.50 & 26.00 \\
\hline 900 & 58.59 & $9.33 b$ & 64.64 & 26.03 \\
\hline \multicolumn{5}{|c|}{ Digestible arginine } \\
\hline 700 & 58.90 & 9.41 & 64.59 & 26.00 \\
\hline 800 & 58.43 & 9.40 & 64.80 & 25.80 \\
\hline 900 & 58.78 & 9.31 & 64.69 & 26.00 \\
\hline 1000 & 58.76 & 9.52 & 64.20 & 26.28 \\
\hline \multicolumn{5}{|c|}{$P$ value } \\
\hline Lys & 0.560 & 0.002 & 0.206 & 0.870 \\
\hline Arg & 0.881 & 0.070 & 0.359 & 0.410 \\
\hline Lys x Arg & 0.793 & 0.541 & 0.395 & 0.736 \\
\hline CV \% & 2.06 & 1.53 & 0.60 & 2.13 \\
\hline
\end{tabular}

$a, b$ - different letters in the same column are statistically different by the $F$ test $(5 \%)$.

mglysine/kg of diet (Rocha et al., 2009) or a quadratic effect with a maximum point of $685 \mathrm{mg}$ lysine $/ \mathrm{kg}$ of diet (Schmidt et al., 2008)

In the present experiment (Table 2), lysine supplementation influenced eggshell quality $(p<0.05)$, and the best eggshell percentage was obtained with 700 mg digestible lysine compared with 900 mg digestible lysine per $\mathrm{kg}$ of diet. This result may have been influenced by the higher intake of the layers fed the diets containing $700 \mathrm{mg}$ of lysine (Carvalho et al., 2012), which consequently increased calcium intake, increasing calcium availability for eggshell formation. The highest lysine supplementation level could potentially change the balance among essential amino acids, which, consequently, could interfere with the hens' metabolism. In this experiment, the antagonism between lysine and arginine was not observed. However, according to Montanhini Neto et al. (2013), the lysine: arginine dietary ratio may affect methionine requirements of broilers, influencing their growth. Higher arginine excretion requires more energy, particularly in uricotelic species, because its molecular structure contains the highest amount of nitrogen among amino acids (Lehninger et al., 1995). Every uric acid molecule is excreted along with a molecule ofglycine. Although birds are able to synthetize glycine, its rate of synthesis is not sufficient speed to supply tissue metabolism needs and to eliminate nitrogen excess (Corzo et al., 2004). Under these conditions, methionine can be limiting due to the higher metabolic requirements formethylation reactions (Silva et al., 2012).
There was no statistical interaction between digestible lysine and arginine interaction for egg-quality parameters in this experiment (Table 3). The effects of different digestible lysine to digestible arginine ratios tested were not statistically significant. Reis et al. (2012) did not find any performance or egg quality differences when testing different arginine: lysine ratios $(1.16,1.21,1.26,1.31$, and 1.36). On the other hand, Carvalho et al. (2012) obtained better performance and higher nutrient metabolizability with different digestible lysine to digestible arginine ratios and concluded that, in order to improve layer performance and to optimize nitrogen metabolism, increases in digestible lysine levels should be accompanied by digestible arginine supplementation.

When amino acid levels were studied separately, digestible lysine levels did not affect egg specific gravity or egg internal quality (Table 3). Other experiments showed that increasing the levels of digestible lysine of layer diets did not affect Haugh units (Jardim Filho et al., 2008; Schmidt et al., 2008; Matos et al., 2009; Rocha et al, 2009; Jardim Filho et al., 2010; Silva et al., 2010;), yolk index (Jardim Filho et al., 2008; Schmidt et al., 2008; Rocha et al, 2009; Jardim Filho et al., 2010), or total egg solids (Jardim Filho et al., 2008; Matos et al., 2009; Jardim Filho et al., 2010).

The digestible arginine levels used in this experiment did not affect egg specific gravity or any egg internal quality parameters (Table 3), except for albumen solids $(p<0.05)$, with a negative quadratic effect of reducing 
Table 3 - Egg components of 24 - to 44 - week - old layers fed increasing levels of digestible lysine (Lys, mg/kg of diet) and arginine (Arg, $\mathrm{mg} / \mathrm{kg}$ of diet).

\begin{tabular}{|c|c|c|c|c|c|c|}
\hline & $\mathrm{SG}^{1}$ & $\mathrm{UH}^{1}$ & $\mathrm{Y} \mathrm{I}^{1}$ & ETS1 & $\mathrm{AS}^{1}$ & YS ${ }^{1}$ \\
\hline \multicolumn{7}{|c|}{ Digestible lysine } \\
\hline 700 & 1.091 & 102.16 & 0.43 & 23.60 & 11.79 & 50.78 \\
\hline 900 & 1.091 & 102.76 & 0.43 & 23.30 & 11.85 & 50.82 \\
\hline \multicolumn{7}{|c|}{ Digestible arginine } \\
\hline 700 & 1.093 & 102.34 & 0.43 & 23.46 & 12.11 & 50.83 \\
\hline 800 & 1.090 & 102.48 & 0.43 & 23.39 & 11.65 & 50.73 \\
\hline 900 & 1.090 & 102.73 & 0.43 & 23.33 & 11.72 & 50.61 \\
\hline 1000 & 1.091 & 102.29 & 0.43 & 23.63 & 11.80 & 51.02 \\
\hline \multicolumn{7}{|c|}{$P$ value } \\
\hline Lys & 0.964 & 0.129 & 0.759 & 0.072 & 0.484 & 0.763 \\
\hline Arg & 0.282 & 0.847 & 0.639 & 0.567 & $0.002^{2}$ & 0.257 \\
\hline Lys x Arg & 0.794 & 0.080 & 0.308 & 0.896 & 0.543 & 0.165 \\
\hline CV \% & 0.36 & 1.05 & 1.43 & 1.91 & 1.97 & 0.80 \\
\hline
\end{tabular}

a, b-different letters in the same column statistically differ. 'Specific gravity (SG), Haugh units (HU), yolk index (YI), whole egg solids (ETS), albumen solids (AS) and yolk solids (YS). ${ }^{2} \mathrm{Y}=22.0930-0.0237007 \mathrm{X}+0.0000134411 \mathrm{X}^{2} / \mathrm{R}^{2}=0.89 /$ minimum point $=881 \mathrm{mg}$

the content up to $881 \mathrm{mg}$ digestible arginine/kg of diet. Rostagno et al. (2011) suggested that the level of $0.866 \%$ of digestible arginine for a feed intake of 93 $\mathrm{g} /$ hen/day is close to the observed in this experiment, which was $94.7 \mathrm{~g} / \mathrm{hen} /$ day.

There was no interaction between digestible lysine and arginine levels for egg quality parameters. Increasing the dietary levels of digestible lysine and arginine reduced eggshell quality and albumen solids, respectively.

The levels of amino acids suggested to improve egg quality are $700 \mathrm{mg}$ of digestible lysine and $700 \mathrm{mg}$ of digestible arginine/kg of feed, corresponding to a digestible lysine: digestible arginine ratio of 100 .

\section{REFERENCES}

Araújo DM, Vilar da Silva JH, Lima MR, Araújo JA, Jordão Filho J, Ribeiro MLG. Níveis de lisina e arginina digestível para poedeiras no pico de postura. Anais da Conferência Apinco de Ciência e Tecnologia Avícola; 2005; Santos, São Paulo. Brasil. p. 136.

Bacila M. Bioquímica veterinária. 2a ed. São Paulo: ROBE; 2003. 583p.

Campos AMA, Rostagno HS, Nogueira ET, Albino LFT, Pereira JPL, Maia RC. Atualização da proteína ideal para frangos de corte: arginina, isoleucina, valina e triptofano. Revista Brasileira de Zootecnia 2012;41(2):326-332.

Carvalho FB, Stringhini JH, Matos MS, Jardim filho RM, Café MB, Leandro NSM, Andrade MA. Performance and nitrogen balance of laying hens fed increasing levels of digestible lysine and arginine. Revista Brasileira de Zootecnia 2012;41(10):2183-2188.

Corzo A, Kidd MT, Burnham DJ, Kerr BJ. Dietary glycine needs of broiler chicks. Poultry Science 2004;83(8):1382-1384

Edmonds MS, Parsons CM, Baker DH. Limiting amino acid in low-protein corn-soybean meal diets feed to growing chicks. Poultry Science 1985;64:1519-1526
Gadelha AC,Dahlke F, Faria Filho DE, Rosa OS, Gonzales E. Interação entre arginina e lisina altera as respostas produtivas e a incidência de problemas de pernas em frangos de corte.l Anais da Conferência Apinco de Ciência e Tecnologia Avícola;2003; Campinas, São Paulo. Brasil. p. 75

Jardim Filho RM, Stringhini JH, Andrade MA, Barini AC, Leandro NSM, Café MB. Qualidade de ovos, parâmetros bioquímicos sanguíneos e desenvolvimento do aparelho reprodutor de poedeiras comerciais Lohmann LSL alimentadas com níveis crescentes de lisina digestível. Acta Scientiarum Animal Science 2008;30(1):25-31.

Jardim Filho RM, Stringhini JH, Andrade MA, Café MB, Leandro NSM, Carvalho FB. Níveis de lisina digetível para poedeiras Hy-Line W-36 em produção. Revista Brasileira de Zootecnia2010;39(4):787-795.

Lehninger AL, Nelson DL, Cox MM. Princípios de bioquímica. $2^{\mathrm{a}}$ ed. São Paulo: SARVIER; 1995. 839p.

Lima MR, Silva JHV.Efeito da relação lisina:arginina digestível sobre o desempenho de poedeiras comerciais no período de postura. Acta Veterinária Brasílica2007;1(4):118-124.

Lonhmann LSL. Manual de poedeira branca. Uberlândia: \{s.n.\}; 2004. 29p.

Macari M, Furlan RL, Gonzales E. Fisiologia aviária aplicada a frangos de corte. Jaboticabal: FUNEP; 2002. 375p.

Matos MS, Leandro NSM, Carvalho FB, Srtinghini JH, Café MB, Lopes $\mathrm{KL}$. Níveis de lisina e treonina digestíveis na ração de poedeiras comerciais sobrequalidade de ovos. Acta Scientiarum Animal Science 2009;31(1):25-29

Montanhini Neto R, Ceccantini ML, Fernandes JIM. Effects of methionine source, arginine: lysine ratio and sodium chloride level in the diets of grower broilers reared under high-temperature conditions. Revista Brasileira de Ciência Avícola. 2013;15(2):151-160.

National Research Council - NRC. Nutrient requirements of poultry. $9^{\text {th }}$ ed. Washington, (DC): National Academic Press; 1994.

Nunes IJ. Nutrição animal básica. 2 ${ }^{\mathrm{a}}$ ed. Belo Horizonte: FEP/MVZ; 1998.

Reis RS, Barreto SLT, Abjaude WS, Dutra DR, Santos M, Paula E. Relationship of arginine with lysine in diets for laying Japanese quails. RevistaBrasileira de Zootecnia 2012;41(1):106-110. 


\section{Egg Quality of Hens Fed Different Digestible Lysine and Arginine Levels}

Rocha TC, Gomes PC, Donzele JL, Barreto SLT, Mello HHC, Brumano G. Níveis de lisina digestível em rações para poedeiras no period de 24 a 40 semanas de idade. Revista Brasileira de Zootecnia2009;38(9):1726-1731.

Rostagno HS,Albino LFT, Donzelle J F, Gomes P C, Ferreira A S, Oliveira RFD, Lopes DCC.Tabelas brasileiras para aves esuínos: composição de alimentos e exigênciasnutricionais.Viçosa (MG): UFV; 2000.

Rostagno HS,Albino LFT,Donzele JL,Gomes PC, Oliveira RF, Lopes DC, Ferreira AS,Barreto SLT. Tabela brasileira para aves e suínos: composição de alimentos e exigência nutricional. Viçosa (MG): UFV; 2011.

Saeg- Sistema de Análises estatísticas e Genéticas. Versão 7.1, Viçosa (MG): UFV; 1998.
Schmidt M, Gomes, PC, Rostagno HS, Albino LFT, Nunes RV, Calderano AA. Exigência nutricional de lisisna digestível para poedeiras leves no segundo ciclo de produção. Revista Brasileira de Zootecnia2008;37(6):1029-1035

Silva LMGS, Murakami AE, Fernades JIM, Dalla Rosa D, Urgani JF. Effects of dietary arginine supplementation on broiler breeder egg production and hatchability. Revista Brasileira de Ciência Avícola 2012;14(4):267273

Silva MFR, Faria DE, Rizzoli PW, Santos AL, Sakamoto MI, Souza HRB. Desempenho e qualidade de ovos de poedeiras comerciais alimentadas com rações contendo diferentes níveis de metionina e lisina. Revista Brasileira de Zootecnia 2010;39(10):2246-2252. 